\title{
Pelagic shrimps (Decapoda: Dendrobranchiata and Caridea) collected during the TALUD XIV cruise in the northern Gulf of California, Mexico
}

\author{
Joel Flores-Anduaga ${ }^{\dagger}$ e Michel E. Hendrickx
}

(JFA) (MEH) Laboratorio de Invertebrados Bentónicos, Unidad Académica Mazatlán, Instituto de Ciencias del Mar y Limnología, Universidad Nacional Autónoma de México, PO Box 811, Mazatlán, Sinaloa, 82000, Mexico. E-mail: michel@ola.icmyl.unam.mx

(JFA) Posgraduate Program, Instituto de Ciencias del Mar y Limnología, Universidad Nacional Autónoma de México, Mexico.

\begin{abstract}
A total of six species of pelagic shrimps were collected during the TALUD XIV cruise aboard the R/V "El Puma", in the northern Gulf of California, in April 2011, including two species of Dendrobranchiata [Eusergestes similis (Hansen, 1903) and Sergia phorca (Burkenroad, 1940)], and three species of Caridea [Pasiphaea americana Faxon, 1893, P. emarginata Rathbun 1902, and P. pacifica Rathbun, 1902]. Additional specimens of the previously reported Maryprocessa pippinae (Wicksten \& Méndez, 1985) were also found among the samples. Most frequently collected species were P. americana $(50 \%$ of total) and $P$. pacifica (36.6\%). Most numerous species in the samples were $P$. pacifica, P. americana and E. similis. Some minor morphological differences not previously recorded in specimens of Pasiphaea pacifica collected elsewhere were detected. These differences might correspond to an intraspecific variation.
\end{abstract}

Key words: East Pacific, northern Gulf of California, Pandalidae, Pasiphaeidae, Processidae, Sergestidae

\section{INTRODUCTION}

Pelagic shrimps of the Mexican Pacific are relatively well known, in particular in the California Current area and in the Gulf of California. The pelagic fauna of SW Mexico, however, has been much less studied and there is a huge gap of records roughly between Banderas Bay and the southern Gulf of Tehuantepec (Hendrickx and EstradaNavarrete, 1989, 1996). Since the first checklist of pelagic shrimps from the East Pacific was made available (Hendrickx and EstradaNavarrete, 1989) only a few contributions have been published on the subject. Guzman and Wicksten $(1998,2000)$ reported on new records of pelagic Pasiphaeidae and on Benthesicymidae from Chile. Wicksten (2002) presented an extensive report on midwater decapods in the NE Pacific, including data related to the presence of 43 species of shrimps in this region. Hendrickx (2008) briefly reported on the presence of Hymenopenaeus doris Faxon, 1893, off Mexico and redescribed the genital appendages of a mature male, and Guzman (2008) provided new records and a synthesis for 79 species of pelagic shrimps reported off Chile. Recently, Hendrickx (2012a) proposed a new genus, Maryprocessa Hendrickx, 2012, to accommodate the only known species of pelagic processid, Processa pippinae Wicksten \& Méndez, 1985, endemic to the East Pacific.

According to Hendrickx and EstradaNavarrete (1996), the pelagic shrimp fauna of the Mexican Pacific comprises 53 species (29 Dendrobranchiata and 24 Caridea), but an 
additional species, Psathyrocaris fragilis WoodMason, 1893, was reported by Hendrickx and Wicksten (2011). Two additional contributions related to pelagic shrimps of the Mexican Pacific were recently published. Hendrickx (2013a) reported 15 species of pelagic shrimps collected during the TALUD I-VII cruises, with Gennadas incertus (Balss, 1927) and Acanthephyra cf. brevirostris Smith, 1885 , recorded for the first time in the Gulf of California, and Hendrickx (2013b) provided new distribution data for Pasiphaea emarginata Rathbun, 1902.

In 1989 a project aimed at collecting deep-water invertebrates and fishes off the Pacific coast of Mexico was initiated (TALUD I-III) and resumed in 2000-2001 (TALUD IVVII). Other collecting cruises were organized from 2005 to 2012 (TALUD VIII-XV) in different areas (see Hendrickx, 2012b), and pelagic shrimps were captured in many samples. This contribution reports on material collected during the TALUD XIV cruise in the northern Gulf of California, Mexico, except for the vast majority of specimens of Maryprocessa pippinae that were reported previously (see Hendrickx, 2012a).

\section{Material and Methods}

The pelagic shrimps reported in this contribution were collected during the ascent of an Agassiz sledge and a benthic sledge operated in deep water in the northern Gulf of California (TALUD XIV cruise, R/V "El Puma”, 5-11 April, 2011). This cruise was organized by the Laboratorio de Invertebrados Bentónicos (LIB), ICML, UNAM. A total of 30 stations were visited in the northern Gulf of California, Mexico, roughly between $28^{\circ} 10^{\prime}$ and $29^{\circ} 10^{\prime} \mathrm{N}$, with depth ranging from 148 and $1346 \mathrm{~m}$. Specimens of pelagic shrimps were separated from the capture and kept in a $4 \%$ formaldehyde solution for 1-2 weeks, washed and preserved in a $70 \%$ ethanol solution. Most material identified and reported herein is deposited in the Regional Collection of Invertebrates at the Mazatlán Marine Station, ICML, UNAM, in Mazatlán, Mexico (EMU).
Identification of species was made using keys, figures and description of Hendrickx and Estrada-Navarrete (1996), although in some cases the original descriptions were also used to confirm some morphological features. Abbreviations used are: CL, carapace length; St, sampling station; NS, unsexed specimens.

\section{RESULTS}

\section{Taxonomic Account}

A total of 418 specimens of pelagic shrimps belonging to six species (two Dendrobranchiata and four Caridea) were collected during the TALUD XIV cruise. Information related to sampling date, position, and sampling depth of each station will be find in Tab. 1 .

Table 1. Position of sampling stations visited during the TALUD XIV cruise in the upper Gulf of California where specimens were collected, and gear used at each station. Depth values are total depth at station (bottom trawl). AS, Agassiz sledge; BS, benthic sledge.

\begin{tabular}{|c|c|c|c|c|c|}
\hline Date & Station & $\begin{array}{l}\text { Latitude } \\
(\mathrm{N})\end{array}$ & $\begin{array}{l}\text { Longitude } \\
\text { (W) }\end{array}$ & Gear & Depth (m) \\
\hline 7 April 2011 & 1 & $28^{\circ} 15^{\prime} 38^{\prime \prime}$ & $111^{\circ} 58^{\prime} 33^{\prime \prime}$ & BS & $208-212$ \\
\hline 7 April 2011 & 2 & $28^{\circ} 14^{\prime} 31^{\prime \prime}$ & $112^{\circ} 08^{\prime} 27^{\prime \prime}$ & BS & $512-525$ \\
\hline 7 April 2011 & 3 & $28^{\circ} 16^{\prime} 03^{\prime \prime}$ & $112^{\circ} 17^{\prime} 40^{\prime \prime}$ & BS & $914-925$ \\
\hline 7 April 2011 & 4 & $28^{\circ} 11^{\prime} 27^{\prime \prime}$ & $112^{\circ} 32^{\prime} 06^{\prime \prime}$ & BS & $435-451$ \\
\hline 8 April 2011 & 9 & $28^{\circ} 20^{\prime} 04^{\prime \prime}$ & $112^{\circ} 21^{\prime} 33^{\prime \prime}$ & AS & $915-922$ \\
\hline 8 April 2011 & 10 & $28^{\circ} 20^{\prime} 50^{\prime \prime}$ & $112^{\circ} 11^{\prime} 40^{\prime \prime}$ & AS & $325-328$ \\
\hline 8 April 2011 & 12 & $28^{\circ} 15^{\prime} 19^{\prime \prime}$ & $112^{\circ} 13^{\prime} 57^{\prime \prime}$ & AS & $286-289$ \\
\hline 8 April 2011 & 14 & $28^{\circ} 36^{\prime} 14^{\prime \prime}$ & $112^{\circ} 28^{\prime} 03^{\prime \prime}$ & BS & $305-316$ \\
\hline 8 April 2011 & 15 & $28^{\circ} 29^{\prime} 30^{\prime \prime}$ & $112^{\circ} 32^{\prime} 43^{\prime \prime}$ & BS & $823-871$ \\
\hline 11 April 2011 & 16 & $28^{\circ} 20^{\prime} 57^{\prime \prime}$ & $112^{\circ} 37^{\prime} 16^{\prime \prime}$ & AS & $276-318$ \\
\hline 9 April 2011 & 19 & $28^{\circ} 37^{\prime} 37^{\prime \prime}$ & $112^{\circ} 41^{\prime} 05^{\prime \prime}$ & BS & $560-580$ \\
\hline 9 April 2011 & 20 & $28^{\circ} 46^{\prime} 29^{\prime \prime}$ & $112^{\circ} 45^{\prime} 40^{\prime \prime}$ & BS & $414-410$ \\
\hline 9 April 2011 & 21 & $29^{\circ} 00^{\prime} 53^{\prime \prime}$ & $112^{\circ} 51^{\prime} 31^{\prime \prime}$ & BS & $412-415$ \\
\hline 9 April 2011 & 22 & $29^{\circ} 05^{\prime} 27^{\prime \prime}$ & $112^{\circ} 46^{\prime} 44^{\prime \prime}$ & BS & $380-390$ \\
\hline 9 April 2011 & 24 & $29^{\circ} 08^{\prime} 06^{\prime \prime}$ & $112^{\circ} 58^{\prime} 42^{\prime \prime}$ & BS & $532-594$ \\
\hline 10 April 2011 & 26 & $29^{\circ} 02^{\prime} 11^{\prime \prime}$ & $113^{\circ} 17^{\prime} 12^{\prime \prime}$ & BS & $1150-1165$ \\
\hline 10 April 2011 & 27 & $29^{\circ} 08^{\prime} 53^{\prime \prime}$ & $113^{\circ} 25^{\prime} 28^{\prime \prime}$ & BS & $860-907$ \\
\hline 10 April 2011 & 28 & $28^{\circ} 42^{\prime} 56^{\prime \prime}$ & $113^{\circ} 03^{\prime} 48^{\prime \prime}$ & BS & $1109-1151$ \\
\hline 11 April 2011 & 29 & $2836^{\prime} 25^{\prime \prime}$ & $112^{\circ} 58^{\prime} 29^{\prime \prime}$ & BS & $627-643$ \\
\hline 11 April 2011 & 30 & $28^{\circ} 32^{\prime} 57^{\prime \prime}$ & $112^{\circ} 59^{\prime} 26^{\prime \prime}$ & BS & $270-309$ \\
\hline 11 April 2011 & 33 & $27^{\circ} 47^{\prime} 52^{\prime \prime}$ & $111^{\circ} 09^{\prime} 30^{\prime \prime}$ & BS & $319-344$ \\
\hline
\end{tabular}

Dendrobranchiata Spence Bate, 1888

Sergestidae Dana, 1852

Eusergestes similis (Hansen, 1903)

Material examined: St. 3, 1 female (CL, 11.85 mm) (EMU-9919-A); St. 20, 2 NS (CL, 10.1- 
$11.79 \mathrm{~mm}), 17$ males (CL, 9.89-11.53 mm), and 9 females (CL, 10.32-13.73 mm) (EMU9920); St. 21, 3 females (CL, 10.32-11.84 mm) (EMU-9921-A); St. 22, 3 females (CL, 11.81-13.88 mm) (EMU-9921-B); St. 24, 1 female (CL, $11.02 \mathrm{~mm}$ ) (EMU-9919-C); St. 26, 5 males (CL, 9.76-12 $\mathrm{mm}$ ) and 4 females (CL, 10.89-11.87 mm) (EMU-9919-B); St. 27, 1 male (CL, $10.53 \mathrm{~mm}$ ) and 2 females (CL, 13.48-13.55 mm) (EMU-9922); St. 28, 11 juveniles (CL, 2.22-4.96 mm), 21 males (CL, 10.43-13.05 mm), and 10 females (CL, 10.41-14.17 mm) (EMU-9923); St. 29, 1 male (CL, $10.36 \mathrm{~mm}$ ) and 1 female (CL, $11.47 \mathrm{~mm}$ ) (EMU-9924) (Fig. 1).

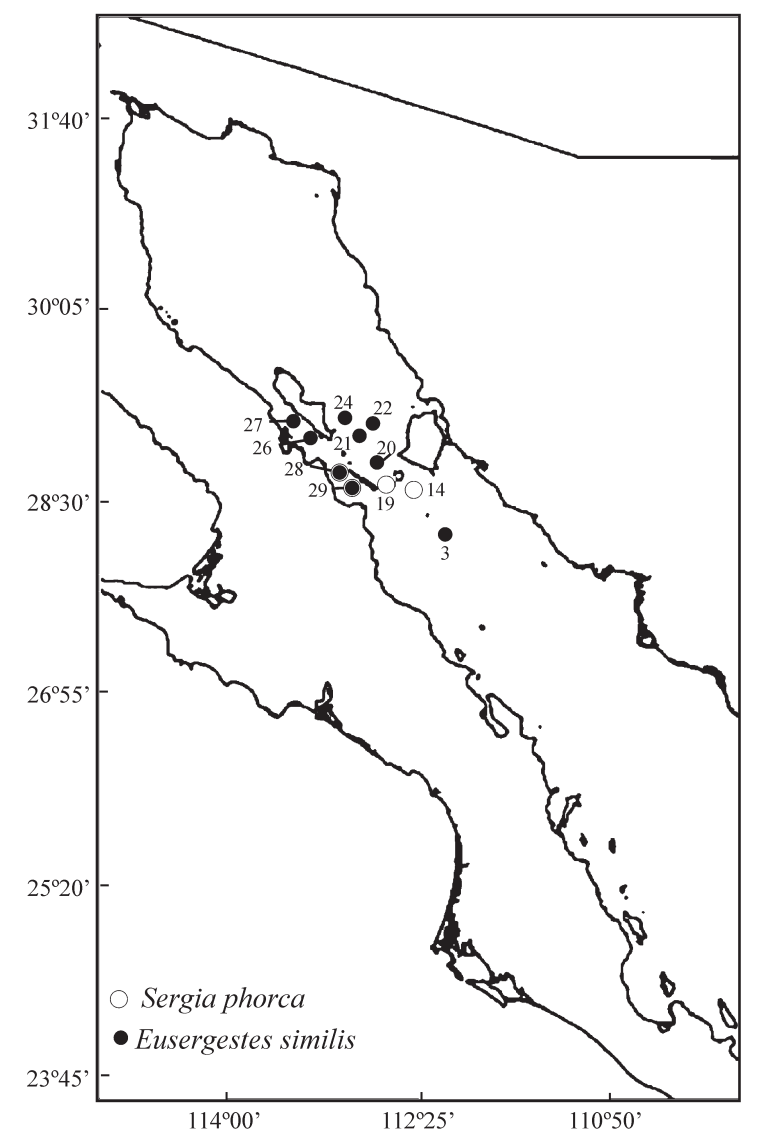

Figure 1. Sampling localities where specimens of Sergia phorca and Eusergestes similis were collected during the TALUD XIV cruise.

Remarks: With a total of 92 specimens obtained in nine out of 30 samples (30\%) (Tab. 2), this species was by far the most common sergestid found in the samples. According to previous records, E. similis is the most common species of the family Sergestidae in the Gulf of California (Hendrickx and Estrada-Navarrete, 1996). A species generally referred to as subarctic, it ranges in the North Pacific from Japan to Washington, and along the coast of North America to the Gulf of California (Schmitt, 1921). It was recently registered for the Southern Hemisphere, off the coast of

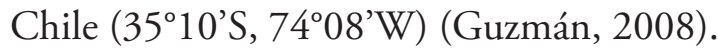

Table 2. Number of specimens of pelagic shrimps collected during the TALUD XIV cruise and number of samples in which each species was found. For comparative purposes, the material of $M$. pippinae reported by Hendrickx (2012a) from the same cruise in similar gear $\left(^{*}\right)$ and in a mid water sample $(* *)$ is included in the table.

\begin{tabular}{lcc}
\hline \multicolumn{1}{c}{ Species } & Samples & Specimens \\
\hline Eusergestes similis (Hansen, 1903) & 9 & 92 \\
Sergia phorca (Burkenroad, 1940) & 4 & 9 \\
Pasiphaea americana Faxon, 1893 & 15 & 97 \\
Pasiphaea emarginata Rathbun, 1902 & 1 & 5 \\
Pasiphaea pacifica Rathbun, 1902 & 11 & 209 \\
Maryprocessa pippinae (Wicksten \& & 2 & 5 \\
Méndez, 1985) & & 48 \\
Maryprocessa pippinae $\left.{ }^{*}\right)$ & 8 & 148 \\
Maryprocessa pippinae $\left(^{* *}\right)$ & 2 &
\end{tabular}

\section{Sergia phorca (Burkenroad, 1940)}

Material examined: St. 14, 1 female (CL, 22.45 mm) (EMU-9925); St. 19, 1 male (CL, 20.84 $\mathrm{mm}$ ) and 1 female (CL, $17.9 \mathrm{~mm}$ ) (EMU9926); St. 28, 1 male (CL, $19.38 \mathrm{~mm}$ ) and 3 females (CL, 21.58-21.86 mm) (EMU-9927); St. 29, 2 males (CL, 18.36-22.26 mm) (EMU9928) (Fig. 1).

Remarks: This species was identified based on the shape of the petasma, the arrangement of the photophores of the scaphocerite, and the shape of the endopod of the uropod. In some specimens, however, the rostrum differs slightly from the description provided by Vereshchaka (2000) for this species. Reported for the Central Gulf of California south to Peru and off the Galapagos Islands by Hendrickx and Estrada-Navarrete (1986) and Hendrickx (2013a), and to Chile by Guzmán (2008), S. phorca is now recorded from the northern Gulf of California. 
Caridea Dana, 1852

Pasiphaeidae Dana, 1852

Pasiphaea americana Faxon, 1893

Material examined: St. 1, 1 NS (CL, 16.73 mm) (EMU-9906); St. 2, 4 NS (CL, 15.59$20.86 \mathrm{~mm}$ ) and 1 ovigerous female (CL, 21.88 mm) (EMU-9907); St. 3, 4 NS (CL, 13.21$19.61 \mathrm{~mm})($ EMU-9908); St. 10, 3 NS (CL, 18.06-20.62 mm) (EMU-9909-A); St. 12, 20 NS (CL, 10.56-21.19 mm) (EMU-9910); St. 14, 3 NS (CL, 15.54-20.33 mm) (EMU9912); St. 16, 1 NS (CL, $19.43 \mathrm{~mm})(\mathrm{EMU}-$ 9909-B); St. 20, 5 NS (CL, 13.25-17.99 mm) (EMU-9911); St. 21, 4 NS (CL, 14.74-19.53 $\mathrm{mm})$ and 1 ovigerous female (CL, $18.62 \mathrm{~mm}$ ) (EMU-9913); St. 22, 26 NS (CL, 11.77-19.94 $\mathrm{mm})$ and 1 ovigerous female (CL, $16.34 \mathrm{~mm}$ ) (EMU-9914); St. 26, 5 NS (CL, 17.7-21.2 mm) (EMU-9915); St. 28, 10 NS (CL, 13.96$19.83 \mathrm{~mm}$ ) (EMU-9916); St. 29, 5 NS (CL, 18.07-20.53 mm) (EMU-9917); St. 30, 1 NS (CL, $14.63 \mathrm{~mm}$ ) and 1 ovigerous female (CL, $20.04 \mathrm{~mm}$ ) (EMU-9918); St. 33, 1 NS (CL, $16.68 \mathrm{~mm}$ ) (EMU-9909-C) (Fig. 2).

Remarks: This is usually the most common species of Pasiphaeidae found in the Gulf of California and along the SW coast of the Baja California Peninsula (Hendrickx and EstradaNavarrete, 1996). During this survey, however, P. pacifica turned out to be also very abundant in the northern Gulf of California (infra). With a total of 97 specimens caught in 15 samples (50\% of total), $P$. americana was the most common species of pelagic shrimp collected during the TALUD XIV cruise. One specimen (St. 22, $16.63 \mathrm{~mm}$.) features two spines in the merus of the left second pereiopods, which is atypical for this species that normally has a single spine (Hayashi, 2004).

Hayashi (2004: 322) presented a key to species of Pasiphaea belonging to the "Pasiphaea cristata" Spence Bate, 1888, group to which $P$. americana belongs, and provided detailled illustrations of the type material used by Faxon $(1893,1895)$ (i.e., the lectotype and one of the paralectotype designated by K.-I. Hayashi).

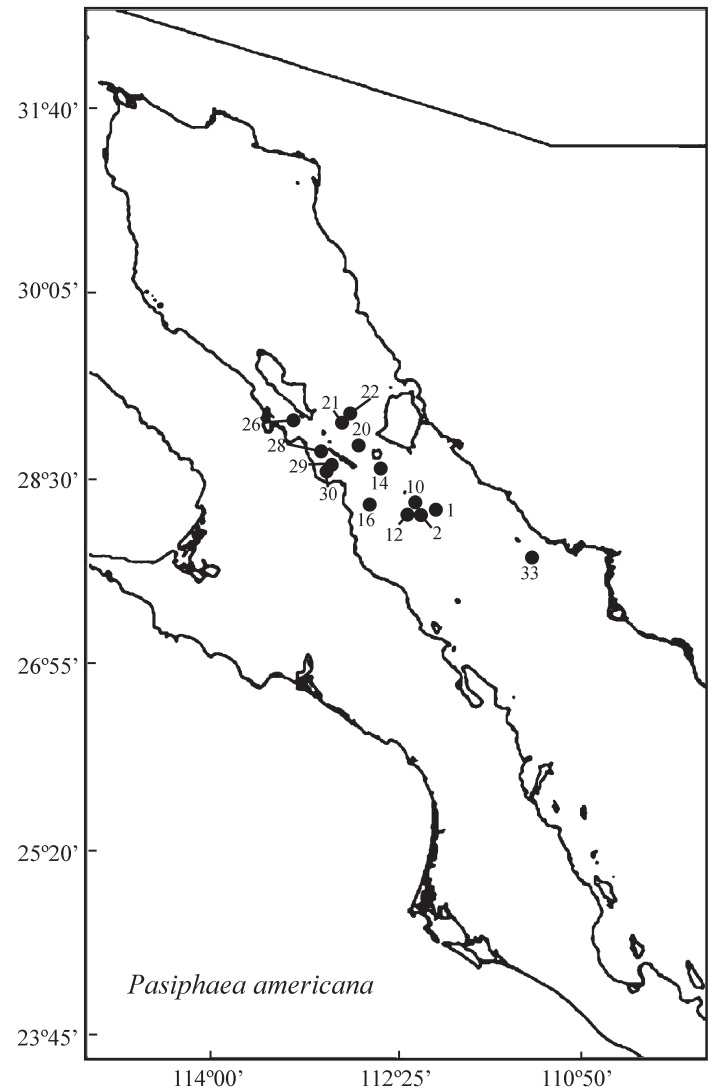

Figure 2. Sampling localities where specimens of Pasiphaea americana were collected during the TALUD XIV cruise.

\section{Pasiphaea emarginata Rathbun, 1902}

Material examined: St. 4, 4 NS (CL, 29.21$33.58 \mathrm{~mm}$ ) and 1 ovigerous female (CL, 30.57 mm) (EMU-9904 and 9905) (Fig. 3).

Remarks: This species had been rarely cited in the Gulf of California (see Schmitt, 1921; Chace, 1937; Hendrickx and EstradaNavarrete, 1996), but recent surveys have shown that it is a relatively common species at depths greater than $300 \mathrm{~m}$ (Hendrickx, 2013a; 2013b). Hendrickx and EstradaNavarrete (1996) mentioned that the merus of the second pair of pereiopods of $P$. emarginata presents "more than one spine" but "less than 10 spines", which is rather ambiguous and finds its origin in confusion. The material reviewed herein has 12-19 spines on the merus of the second pair of pereiopods.

Neither the original description (Rathbun, 1902) nor the subsequent short 
description by Rathbun (1904) included characteristics of the pereiopods. In his monograph of California decapod crustaceans, Schmitt (1921) presented an adaptation of Rathbun's (1902, 1904) descriptions without any further remarks. Chace (1937) only reported some specimens without morphologic description.

Pasiphaea emarginata is easily recognised for its produced forehead, its sharp triangular rostrum and the long posterior dorsal carina; the strongly carinated lateral portion of the carapace is also typical of this species.

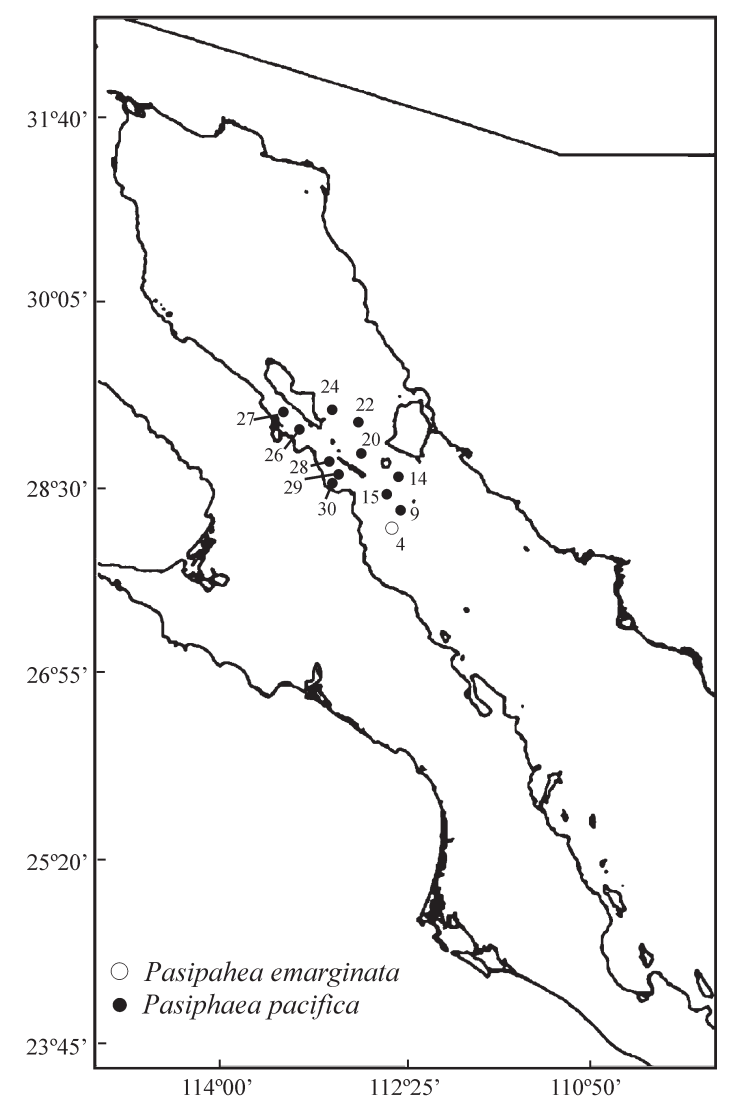

Figure 3. Sampling localities where specimens of Pasiphaea emarginata and $P$. pacifica were collected during the TALUD XIV cruise.

Pasiphaea pacifica Rathbun, 1902

Material examined: St. 9, 11 NS (CL, 14.74$19.53 \mathrm{~mm}$ ) and 1 ovigerous female (CL, 18.62 mm) (EMU-9893); St. 14, 47 NS (CL, 12.7$15.16 \mathrm{~mm}$ ) (EMU-9894); St. 15, 3 NS (CL, 13.01-16.13 mm) (EMU-9895); St. 20, 32 NS (CL, 8.93-16.73 mm) (EMU-9896); St. 22, 2 NS (CL, 11.74-13.78 mm) (EMU-
9897); St. 24, 8 NS (CL, 12.23-16.85 mm) and 4 ovigerous female (CL, 14.49-15.09 $\mathrm{mm}$ ) (EMU-9898); St. 26, 12 NS (CL, 17.54$9.46 \mathrm{~mm}$ ) and 3 ovigerous female (CL, 14.82$15.26 \mathrm{~mm}$ ) (EMU-9899); St. 27, 5 NS (CL, 4.65-16.27 mm) (EMU-9900); St. 28, 64 NS (CL, 5.05-18.64 mm) (EMU-9901); St. 29, 13 NS (CL, 12.21-16.92 mm) (EMU-9902); St. 30, 4 NS (CL, 12.55-15.51 mm) (EMU9903) (Fig. 3).

Remarks: With a total of 289 specimens in 11 samples (37\% of total samples), P. pacifica is by far the most numerous species collected during this survey and even outnumbered P. americana which was the most common species in the samples.

The specimens of this species have characteristics that differ from those previously reported for specimens collected outside the Gulf of California. According to Butler (1980) and Hendrickx and Estrada-Navarrete (1996), typical $P$. pacifica have $0-4$ spines on the merus of the first pair and 8-11 spines on the merus of the second pair. All the specimens examined herein, however, lack spines on the merus of the first pair and the number of spines on the merus of the second pair varies from 2 (in small specimens) to 10 (in large specimens). In juveniles, the branchiostegal spine extends beyond the anterolateral edge of the caparace. It gradually migrates backward as the specimens grows and eventually no longer exceeds the edge of the carapace.

In its review of the "Pasiphaea alcocki" Wood-Mason, 1891 species group, in which belongs P. pacifica, Hayashi (2006: 228) examined the type material of the latter, noting that the merus of the first pereiopod is unarmed or bears one spine, while in the second pereiopod the merus is armed with 7-8 spines. The adults specimens examined during this survey fit with the description and illustrations provided by Hayashi (2006) and previous authors, including the original description. Observed variations are therefore considered intraspecific and related to the growth of this species. 


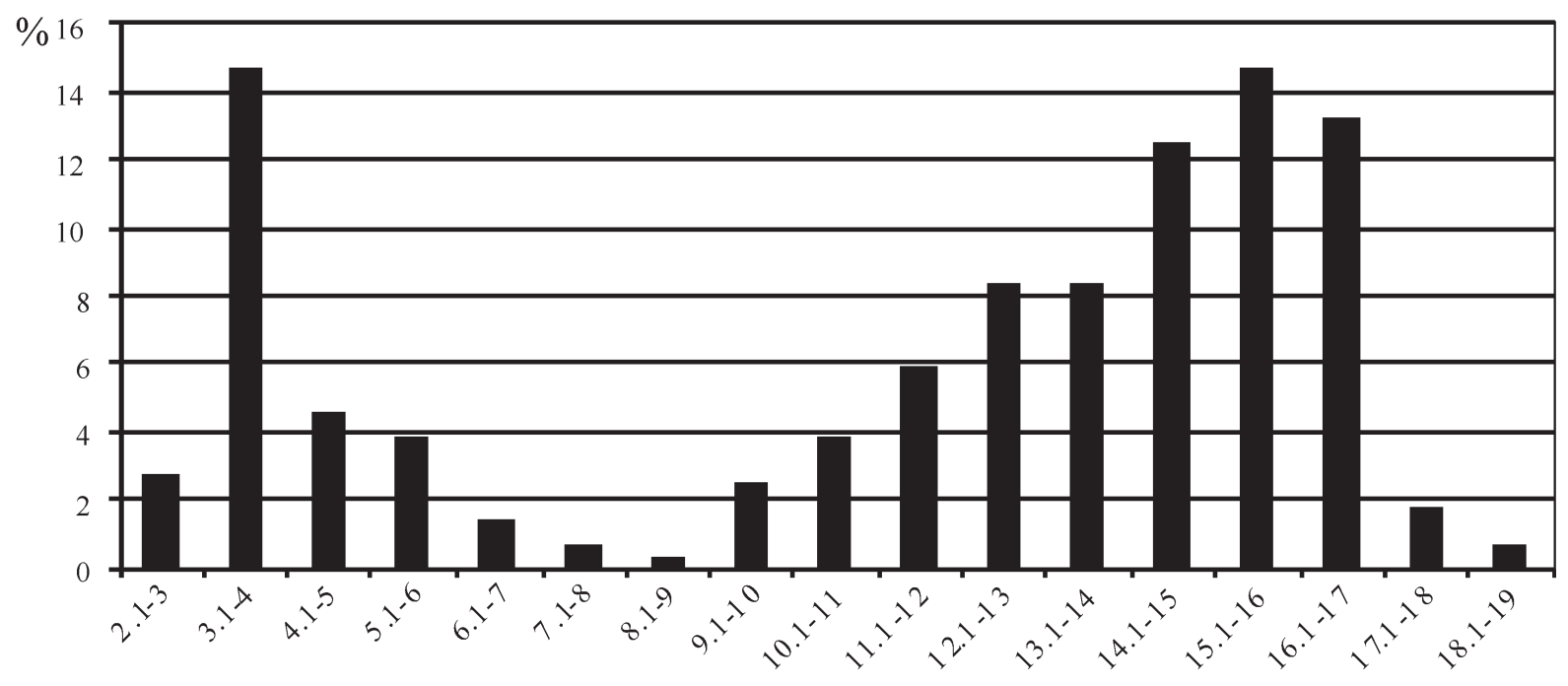

Size $(\mathrm{CL}, \mathrm{mm})$

Figure 4. Size distribution of Pasiphaea pacifica collected during the TALUD XIV cruise.

Size distribution of the material collected during the TALUD XIV cruise clearly indicates the presence of two populations (Fig. 4). The presence of a large amount of juveniles and ovigerous females in the northern Gulf of California indicates that this area represents an important reproductive center for $P$. pacifica.

The distribution of the TALUD XIV material of this species in the Gulf clearly matches the distribution presented by Hendrickx and Estrada-Navarrete (1996) who noted that all known records corresponded to latitudes higher than $27^{\circ} \mathrm{N}$. As in other cases of disjunctive species distribution, it is not clear how the northern Gulf population is related to the California-northern Baja California population. Morphological variations might indicate that a different, endemic species occurs in the northern Gulf of California. Due to an apparently tight isolation process, the Gulf of California population might represent ideal conditions for a speciation process to occur, particularly in the northern Gulf (see Mayer, 1974; Krygyer and Wasmer, 1988; Hendrickx and Serrano, 2013). It would seem, however, that a molecular analysis combined with a thorough morphological study is needed in order to support a possible recognition of a distinct species within the Gulf.
Processidae Ortmann, 1890

Maryprocessa pippinae (Wicksten \& Méndez, 1985)

Material examined: St. 20, 1 NS (CL, 7.45 mm) (EMU-9929-A); St. 28, 4 NS (CL, 2.83$8.79 \mathrm{~mm}$ ) (EMU-9929-B); St. 30, 1 NS (CL, $8.38 \mathrm{~mm}$ ) (EMU-9929-C).

Remarks: This material was misplaced and it is the complement of the large series of specimens of this species that were reported earlier from the same cruise (see Hendrickx, 2012a).

\section{DisCUSSION}

This contribution includes newly reported material for two species of Dendrobranchiata and four species of Caridea. Considering this material, caught in bottom gears during their ascent to the surface, the most frequently collected species was Pasiphaea americana (present in 15 out of 30 samples, or $50 \%$ ), followed by P. pacifica (37\%), and Eusergestes similis (30\%). These three species put together represent almost $96 \%$ of the specimens examined in this study. Together with Maryprocessa pippinae, reported as one of the dominant pelagic species in the area by Hendrickx (2012a; 48 specimens in two bottom trawl gear and 148 specimens in two 
mid water samples; see Tab. 2), these four species of shrimps dominated the pelagic realm of the northern Gulf of California.

Sergia phorca was collected in four stations $(14,19,28,29)$, with a total of nine specimens only. Despite of this very low abundance, these records are the first for the upper Gulf of California. Hendrickx and Estrada-Navarrete (1996) reported this species up to the central Gulf of California $\left(27^{\circ} 23^{\prime} \mathrm{N}\right.$, 111 $26^{\prime} \mathrm{W} ;$ Templeton Crocker Expedition), and records from Hendrickx (2013a) were all from off the coast of Sinaloa, in the SE Gulf of California. Thus, present record increases the northernmost distribution limit of $S$. phorca by $1^{\circ} 20^{\prime}$ of latitude to the north. In the case of $P$. emarginata, the only sample obtained during the survey was caught at station 4 $\left(28^{\circ} 11^{\prime} 27^{\prime \prime} \mathrm{N}, 112^{\circ} 32^{\prime} 06^{\prime \prime} \mathrm{W}\right)$, in an area where this species has been recently reported (see Hendrickx, 2013b).

Considering all stations, the overall sampling depth range was comprised between 208 and $1165 \mathrm{~m}$ depth (Tab. 1), i.e., shrimps were all captured at unknown depths in this interval during the recovery of the sampling gear. Total depths registered at stations where species were captured were 412-1165 m for $S$. similis, 305-1151 m for $S$. phorca, 270-1165 m for $P$. pacifica and $P$. americana, and 435-451 $\mathrm{m}$ for P. emarginata.

Because of its unique oceanographic attributes and broad seasonal water temperature range, Brusca and Hendrickx (2010) mentioned that the northern Gulf of California provides a refuge for many disjunct warm-temperate (i.e., Californian) species that are not found in the Central or Southern Gulf. It perhaps also explains the high invertebrate endemicity recorded for the Northern Gulf. Morphologic variations observed in the specimens of Pasiphaea pacifica probably correspond to an intraspecific variation due to reduced genetic exchange with populations outside of the Gulf of California, but the presence of a different, endemic species of Pasiphaea in the area cannot be discarded a priori, all the more considering that the northern Gulf of California is the shelter for several recently described abundant, endemic, species of decapod crustaceans (see Hendrickx 2012a, 2012c; Hendrickx and Ayón-Parente, 2012).

The northern Gulf of California is an important area for a resident population of the fin whale [Balaenoptera physallus (Linnaeus, 1758)] in the summer and fall (Urban, 2010), and the presence of abundant populations of pelagic shrimps certainly plays an important role in the feeding habits of this species of marine mammals.

ACKNOWLEDGEMENTS - This contribution is dedicated to the memory of Joel Flores-Anduaga, dedicated student of the Laboratorio de Invertebrados Bentónicos who tragically passed away when this work and his Master degree thesis were in progress. The authors thanks all colleagues, students, and crew members for their help in sampling activities aboard the R/V "El Puma" during the TALUD XIV cruise, and Mercedes Cordero for the final edition of this manuscript. Shiptime of the research cruise TALUD XIV carried out onboard the R/V "El Puma" was funded by Universidad Nacional Autónoma de México.

\section{REFERENCES}

Brusca, R.C. and M.E. Hendrickx. 2010. Invertebrate Biodiversity and Conservation in the Gulf of California. Chapter 4. p. 72-95. In: Brusca, R.C. (ed) The Gulf of California. Biodiversity and Conservation. Arizona-Sonora Desert Museum Studies in Natural History. ASDM Press and University of Arizona Press.

Butler, T.H. 1980. Shrimps of the Pacific coast of Canada. Canadian Bulletin of Fish and Aquatic Sciences, 902: 1-280.

Chace, Jr., F.A. 1937. The Templeton Crocker Expedition. VII. Caridean decapod Crustacea from the Gulf of California and the west coast of Lower California. Zoologica; Scientific Contributions of the New York Zoological Society, 22(8): 109-138.

Faxon, W. 1893. Reports on the dredging operations off the west coast of Central America to the Galapagos, to the west coast of Mexico, and in the Gulf of California, in charge of Alexander Agassiz, carried on by the U.S. Fish Commission "Albatross" during 1891, lieut. Commander Z.L. Tanner, U.S.N., commanding. VI. Preliminary descriptions of new species of Crustacea. Bulletin of the Museum of Comparative Zoology at Harvard University, 24(7): 149-220.

Faxon, W. 1895. Reports on an exploration off the west coast of Mexico, Central and South America, and off the Galapagos Islands, in charge of Alexander Agassiz, carried on by the U.S. Fish Commission steamer "Albatross", during 1891, lieut. Commander Z.L. Tanner, U.S.N., commanding. XV. The stalk-eyed Crustacea. Memoirs of the Museum of Comparative Zoology at Harvard College, 18: 1-292. 
Guzmán G.G. 2008. Camarones pelágicos (Crustacea: Decapoda) en aguas del Pacífico sureste. Contributions to the Study of East Pacific Crustaceans. [Contribuciones al Estudio de los Crustáceos del Pacífico Este], 5(1): 27-45. (Instituto de Ciencias del Mar y Limnología, UNAM. México).

Guzmán G.G. and M.K. Wicksten 1998. Nuevos registros de camarones de la familia Pasiphaeidae (Crustacea: Decapoda) en el norte de Chile (18 a $22^{\circ}$ Lat Sur, $70^{\circ}$ a 72 Long W). Gayana Zoología, 62(2): 203-210.

Guzmán G.G. and M.K. Wicksten 2000. The subfamily Benthesicyminae Bouvier, 1908 (Decapoda, Dendrobranchiata) in northern Chile $\left(18^{\circ}\right.$ to $\left.22^{\circ} \mathrm{S}\right)$. Crustaceana, 73: 925-931.

Hayashi, K.-I., 2004. Revision of the Pasipheae cristata Bate, 1888 species group of Pasiphaea Savigny, 1816, with descriptions of four new species, and referral of $P$. australis Hanamura, 1989 to Alainopasiphaea Hayashi, 1999 (Crustacea, Decapoda, Pasiphaeidae). In: Marshall, B. and Richer de Forges, B. (eds), Tropical Deep-Sea Benthos, 23. Mémoires du Muséum national d' Histoire naturelle, 191: 319-373.

Hayashi, K.-I., 2006. Revision of the Pasipheae alcocki species group (Crustacea, Decapoda, Pasiphaeidae). In: Richer de Forges, B. and Justine, J.-L, (eds), Tropical Deep-Sea Benthos, 24. Mémoires du Muséum national d' Histoire naturelle, 193: 193-241.

Hendrickx, M.E. 2008. New records and notes on decapod crustaceans in the east Pacific. Crustaceana, 81(8): 999-1006.

Hendrickx, M.E. 2012a. Distribution and abundance of the pelagic processid Processa pippinae Wicksten \& Méndez, 1985 (Crustacea, Decapoda, Caridea, Processidae), collected during the TALUD XIV cruise in the Gulf of California, Mexico, and description of a new genus. Crustaceana, 85(4-5): 463-472.

Hendrickx, M.E. 2012b. Operaciones oceanográficas en aguas profundas: los retos del pasado, del presente y del proyecto TALUD en el Pacífico mexicano (1989-2009). p. 23-104. In: P. Zamorano, M.E. Hendrickx and M. Caso (eds), Biodiversidad y comunidades del talud continental del Pacífico mexicano. P. Zamorano, Secretaría del Medio Ambiente y Recursos Naturales (SEMARNAT), Instituto Nacional de Ecología (INE), México.

Hendrickx, M.E. 2012c. Squat lobsters (Crustacea: Decapoda: Galatheoidea and Chyrostyloidea) collected during the TALUD XIV cruise in the Gulf of California, Mexico, and rediscovery of Gastropthychus perarmatus (Haig, 1968) in the eastern Pacific. Zootaxa, 3418: 28-40.

Hendrickx, M.E. 2013a. Pelagic shrimps collected during the TALUD I-VII cruises aboard the R/V "El Puma" in the SE Gulf of California, Mexico. Crustaceana, 86(4): 437-448.

Hendrickx, M.E. 2013b. Prevalence and distribution of the dinoflagellate Thalassomyces californiensis Collard, 1966 (Ellobiopsidae) on Pasiphaea emarginata Rathbun, 1902 (Crustacea: Decapoda: Caridea: Pasiphaeidae), off Western Mexico. Crustaceana, 86(6): 693-703.

Hendrickx, M.E. and F.D. Estrada Navarrete. 1989. A checklist of the species of pelagic shrimps (Penaeoidea and Caridea) from the eastern Pacific with notes on their geographic and depth distribution. CalCofi Reports, 30: 104-121.
Hendrickx, M.E. and F.D. Estrada Navarrete. 1996. Los camarones Pelágicos (Crustacea: Dendrobranchiata y Caridea) del Pacífico mexicano. Comisión Nacional para el Conocimiento y Uso de la Biodiversidad e Instituto de Ciencias del Mar y Limnología, UNAM, Mexico, 157 pp.

Hendrickx, M.E. and M. Ayón-Parente. 2012. First record of Prionocrangon Wood Mason \& Alcock, 1981 (Crustacea: Decapoda: Caridea: Crangonidae) in the East Pacific and description of a new deepwater species from western Mexico. Zootaxa, 3205: 63-68.

Hendrickx, M.E. and D. Serrano. 2013. Effects of the oxygen minimum zone on squat lobsters distribution in the Gulf of California, Mexico. Central European Journal of Biology, DOI: 10.2478/s11535-0130165-6.

Hendrickx, M.E. and M.K. Wicksten. 2011. New distribution ranges and records of caridean shrimps (Crustacea: Decapoda: Caridea) from the west coast of Mexico. Hidrobiologica, 21(1): 26-33.

Krygier, E.E. and R.A. Wasmer. 1988. Zoogeography of pelagic shrimps (Natantia: Penaeidea and Caridea) in the North Pacific Ocean (with synopses and keys to the species of the subarctic and transitional zones). Bulletin of the Ocean Research Institute, University of Tokyo, 26(1): 43-98.

Mayer, E. 1974. Populations, Species, and Evolution. An Abridgment of Animal Species and Evolution. Harvard University Press, Cambridge, Massachusetts, 453 pp.

Rathbun, M.J. 1902. Descriptions of new decapod crustaceans from the west coast of North America. Proceedings of the United States National Museum, 24(1272): 885-905.

Rathbun, M.J. 1904. Decapod crustaceans of the northwest coast of North America. Harriman Alaska Expeditions, 10: 1-190.

Schmitt, W.L. 1921 The marine decapod Crustacea of California with special reference to the decapod Crustacea collected by the United States Bureau of Fisheries Steamer "Albatross" in connection with the biological survey of San Francisco Bay during the years 1912-1913. University of California Publications in Zoology, 23: 1-470.

Urban R., J. 2010. Marine mammals of the Gulf of California. P. 188-209. In: Brusca, R.C. (ed), The Gulf of California. Biodiversity and Conservation. Arizona-Sonora Desert Museum Studies in Natural History. ASDM Press and University of Arizona Press.

Vereshchaka, A.L. 2000. Revision of the genus Sergia (Decapoda: Dendrobranchiata: Sergestidae): taxonomy and distribution. Galathea Reports, 18: 69-207.

Wicksten, M.K. 2002. Midwater decapods of the Northeastern Pacific. In: M.E. Hendrickx (ed), Contributions to the Study of East Pacific Crustaceans. [Contribuciones al Estudio de los Crustáceos del Pacifico Este], 1: 127-144. (Instituto de Ciencias del Mar y Limnología, UNAM. México). 